\title{
MATCHMAKING AND MARRIAGE NARRATIVES OF ISRAELIS OF CARPATHO-RUSYN ORIGIN
}

\author{
Ilana Rosen
}

\begin{abstract}
The Jews of Carpatho-Rus', presently the western part of Ukraine, were largely decimated in the Holocaust as part of Hungarian Jewry. Until then and more specifically in the interwar period, in which the region was ceded to Czechoslovakia, Carpatho-Rusyn Jews were a community of about 113,000 souls, living in an area of around 100,000 square kilometres. Most of them were Orthodox, often Hasidic, a few thousand were Zionist, and even fewer turned to communism; many of them were farmers or handymen or small industry workers. After the Holocaust, the survivors rebuilt their lives in Israel and the West, though some returned to Carpatho-Rus'. Throughout the $1990 \mathrm{~s}$, Israeli and American organisations of former Carpatho-Rusyn Jews joined forces to facilitate the study of their interwar culture and Holocaust history and experiences by Israeli universities. These efforts yielded two research projects in which I took part and recorded around five hundred narratives belonging to various genres, mainly legend and personal narrative, as well as a few dozen full life histories. The six matchmaking and marriage narratives (plus two adjacent glosses) presented and analysed in this article deal with the following phenomena and issues: tradition vs. modernity, romantic fulfilment vs. tragic separation in the shadow of the war and the Holocaust, and families established on the route to British Mandate ruled Israel/Palestine (I/P), or the State of Israel as of 1948.
\end{abstract}

Keywords: Carpatho-Rus', Central Europe, family narrative, Holocaust, Hungary, immigration, interwar, Jewish studies, marriage, matchmaking, personal narrative

\section{INTRODUCTION: JEWS FROM CARPATHO-RUS' WITHIN THE ISRAELI MULTICULTURE}

The Jews of Carpatho-Rus', presently the western part of Ukraine, were largely decimated in the Holocaust together with most of Hungarian Jewry (Segal 2013). Until the Holocaust, and more specifically in the interwar period, they were a community of about 113,000 souls living in an area of around 100,000 square kilometres, which was divided into the four historical Austro-Hungarian counties of Marmaros, Ung, Ugocsa, and Bereg, at the time under Czechoslovak rule. They lived in dozens of communities varying from large towns like 
Munkács/Mukačevo, Ungvár/Užhorod, and Beregszász/Berehovo to small towns and villages. Most Carpatho-Rusyn Jews were Orthodox, generally Hasidic, though there were also followers of the more westerly oriented Rabbi Moshe Sofer (Hatam Sofer) dynasty. A few thousand were Zionist; even fewer turned to communism. A relatively high percentage of this Jewry were farmers and workers, much like their non-Jewish neighbours, and in conspicuous contrast to the typical image of more easterly shtetl (Yid. 'small town') Jews (Magocsi 1974; Rothkirchen 1977; Jelinek 2007). The Jews of Carpatho-Rus' lived in relative peace and mutual respect with their mostly rural, Orthodox Catholic host society, which itself was divided into several Rusyn/Ruthenian communities, as well as with Ukrainians, Hungarians, Romanians, and Germans living in the region (Hann 2006; Orla-Bukowska 2004; Rusinko 2003).

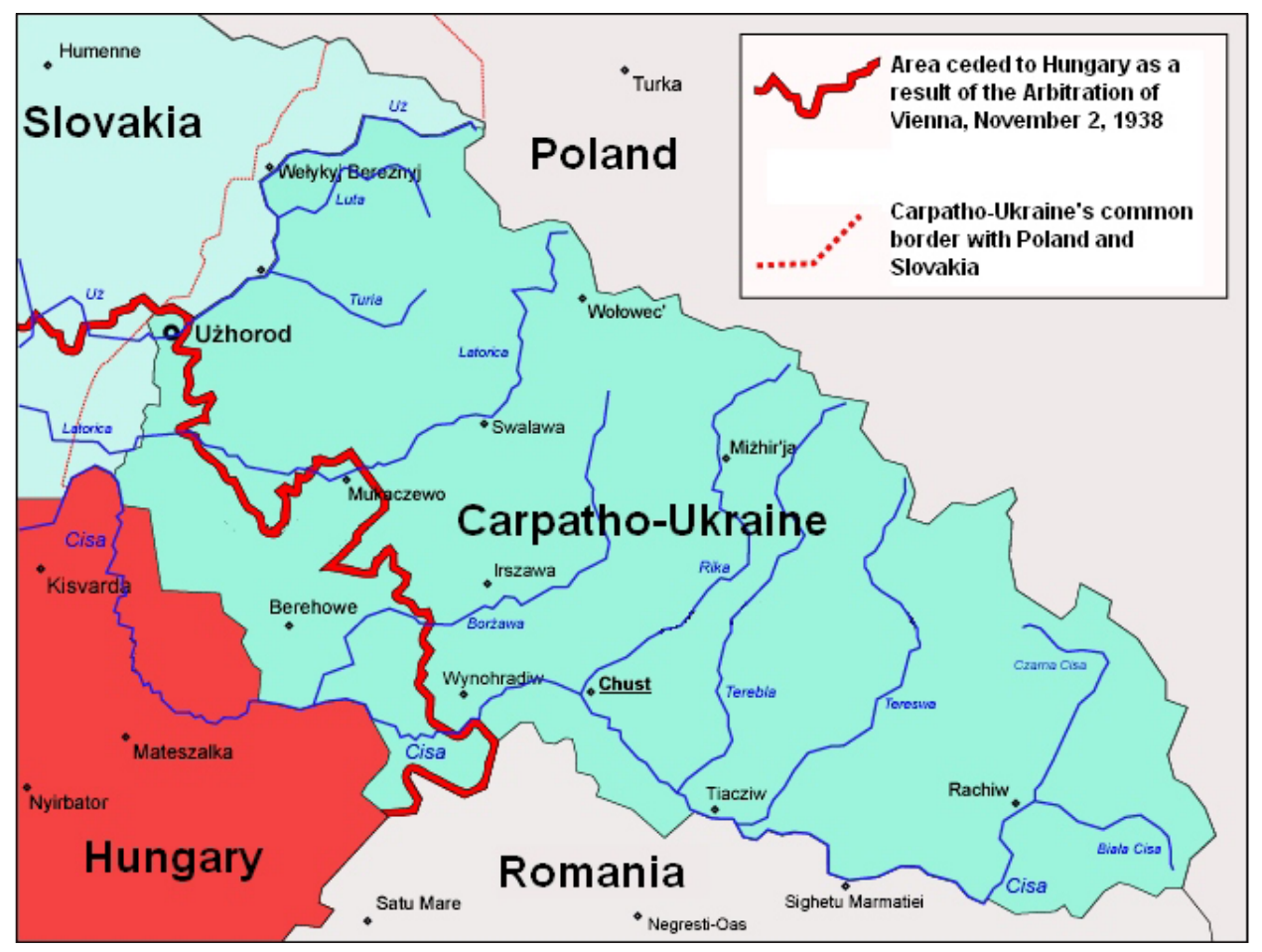

Figure 1. Map of Carpatho-Rus' (http://en.wikipedia.org/wiki/Carpathian_Ruthenia). 
After the Holocaust, the few thousand Carpatho-Rusyn Jewish survivors rebuilt their lives mainly in Israel and in the West, although some returned to or remained in the region. During many decades afterward, the survivors and others who had left early on were busy creating their new lives, families, and homes. As they matured, though, they realised that, like other Israeli groups (Hebrew: edot), they had their own history, identity, experiences, narratives, and folklore (Rosen 2009: 107-108). To this we may add their drive to perpetuate and literally salvage their past lives, families, and entire communities that were destroyed in the Holocaust. In light of all this, throughout the 1990s and 2000s, Israeli and American organisations of former Carpatho-Rusyn Jews joined forces to facilitate the study of their history and culture by Israeli universities. These efforts yielded two research projects. One was carried out at the Diaspora Research Institute (presently The Goldstein-Goren Center) at Tel Aviv University, and included Yeshayahu Jelinek's historical study and my own folkloristic study of interwar Carpatho-Rusyn Jewish communities (Jelinek 2007 (Heb. 2003); Rosen 1999). The second project, mine only, was already a result of the awareness created by the first, and it was carried out at the Institute of Contemporary Jewry of the Hebrew University at Jerusalem. In this project I offered a close reading of the entire life histories of fourteen Israeli Holocaust survivors from Carpatho-Rus' (Rosen 2004). The declared objective of both my projects was - following the wish or urge of the studied community - to recapture, as lively and authentically as possible, the actual experiences of these tradition-observant Jews, their daily routines, life cycle or year cycle highlights, occupations, formal and informal ethos, relationships, figures, and memories, as well as the informants' retrospective views on all these. For this purpose, I devised a detailed questionnaire to be used in the interview and storytelling meetings, including those carried out by a few volunteering ad-hoc research assistants of the community, like Zipora Nemesh and Sara Udi in this article (Rosen 1999: 184-185).

In the interview-meetings with individuals and at times small groups of informant-narrators, we usually spoke Hebrew, but occasionally the interviewees lapsed into Hungarian, Yiddish, or Carpatho-Ruthenian dialects, especially when talking about terms, proverbs, sayings, punch lines and other phraseological or formulaic speech. All in all, my fieldwork with Israelis of Carpatho-Rusyn origin yielded a collection of around 500 narratives belonging to various genres, mainly legend and personal narrative, as well as a few dozen full life histories, and dealing with many themes related to the narrators' interwar life in the region. This entire corpus was recorded throughout the 1990s and the early 2000s all over Israel, in the homes of the narrators, in cafés, or in a nearby university, from some 65 community elders, 40 men and 25 women. This entire collection 


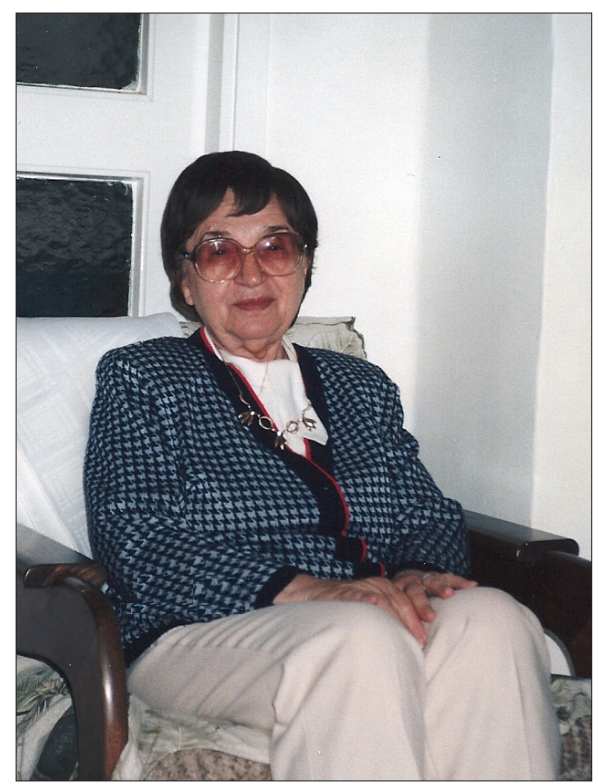

Figure 2. Zipora Nemesh. Photograph by Ilana Rosen 1995.

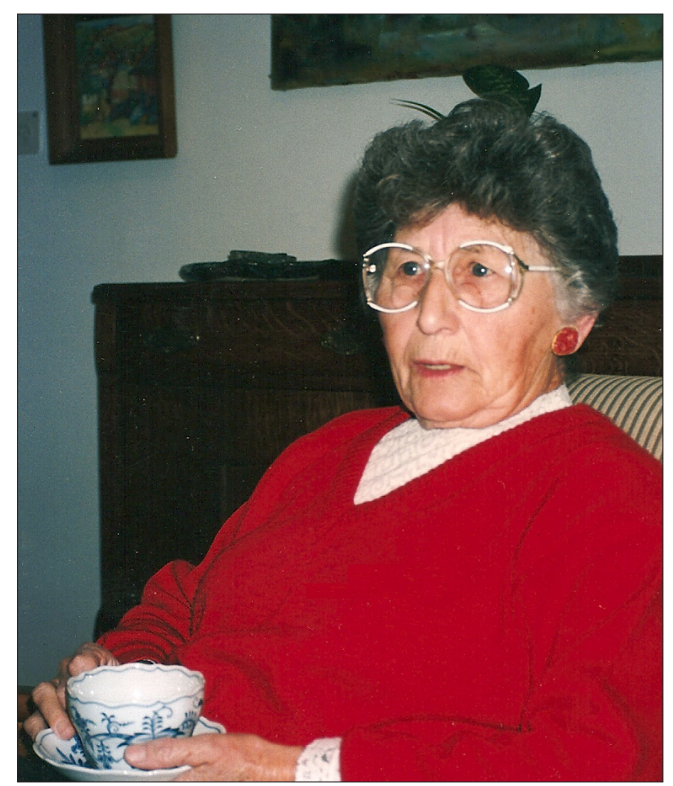

Figure 3. Sara Udi. Photograph by Ilana Rosen 1995.

is presently stored at the Tel Aviv University Diaspora Research Center as well as at IFA, the Dov Noy Israel Folktale Archives at Haifa University. A selection including 180 of these narratives appears in my book, titled Ma'ase she-haya... (Once There Was...) (1999), under the following thematic headings: Jewish life in Carpatho-Rus', livelihood and Torah learning, Hasidism vs. Zionism (see also Rosen 2008), generations or the life cycle, man and woman, wonder tales, Jews and gentiles, and the Holocaust.

\section{JEWISH MATCHMAKING AND MARRIAGE AS ETHOS AND NARRATIVE TRADITION}

The topics of courtship, matchmaking, marriage, marital life and - more generally - gender relations naturally came up often in the interview meetings, whether when discussing one's own family or when telling about interesting, extraordinary events in the environment of the narrators. In Jewish societies, marriage and the procedures leading up to it were and still are key rituals that 
perpetuate the continuity of Jewish life from the era of the Biblical patriarchs and matriarchs, prophets and kings, throughout the various exiles, culminating in present-day diasporas or Jewish centres and the State of Israel. Therefore it is no surprise that marriage in Judaism was and still is a vital and innovative field of research. In recent decades, the study of Jewish marriage has become interdisciplinary as well as opened up to the experiences of Others, e.g., women, queer people (Ochs 2011), and individuals with physical and mental handicaps, both within Orthodoxy and in other streams. Historical studies point to continuity in the laws, rules and customs of Jewish marriage, together with changes caused by the proximity and influence of surrounding societies (Berger 2005). For example, Steven Lowenstein points to the impact of Central European Protestant society on the rise in the age of marriage among the Jews that lived within these societies in early modern times (Lowenstein 1994); and Marsha L. Rozenblit focuses on the courting stage in Viennese Jewish society during the 1920s (Rozenblit 2011), whereas David Biale surveys in more general terms the modernisation processes undergone by Jewish societies in the last few hundred years, with a focus on the practice of marriage (Biale 1983). An indepth historical view of the practice of marriage in Judaism reveals that it was and still is viewed as an overt economic contract or business deal (Novak 2005; Grossbard 2007; Jackson 2011), as reflected also in quite a few of the narratives in this article. In addition to the examination of the practical, pragmatic sides of Jewish marriage, scholars have also studied it as a mental, psychological process, and as one of the rites of passage in the Jewish life cycle (Bulka 1989). Finally, contemporary Jewish gender studies have explored and emphasised women's experiences and perspectives regarding matchmaking and marriage (Broyde \& Ausubel 2005; Baskin 2010; Kaplan \& Dash Moore 2011).

Since couple relationships are the foundation for all societal existence and cultural continuity, they are viewed in probably most if not all civilisations as key issues of the community, and people deal with them intensively. Almost all collections of folk literature, of any society, have stories dealing with malefemale relationships, whether from the male or female perspective. In most traditional collections, gender and couple relationships are addressed in the genre of fairytale, which is romantic and fantastic by nature, as well as in gnomic or minor genres such as proverbs, riddles, or jokes, all of which express and reflect traditional in-group as well as universal folk wisdom accumulated over many years and ever renewing (Shenhar 1983; Greenbaum Ucko 1990). The topic of matchmaking and marriage, which was touched upon in 10-12 of the 500 narratives I recorded in my Carpatho-Rusyn research projects, presents a crossroads of intertwining themes in the lives and lore of this group, and is thus proven to be, or to have been, a significant part of their milieu. Moreover, 
this selection of personal narratives shows that, with regard to a community telling about its past life that was destroyed long ago, even a romantic subject receives significant expression in realistic, historical terms and genres, which historians call oral and bottom-up history (Rosen 2009: 110-112). These narratives demonstrate that people remember and narrate the ways that their parents met, they recall marriages of individuals with physical and mental handicaps (though I do not deal with this subject here due to space constraints), they tell stories about couples whose relationships developed in the shadow of World War II and the Holocaust, and about those who never consummated their love because of these events.

Considering the issue of family storytelling that seems to be lurking behind the present chain of narratives and their analytic discussion, it should be clarified that though it might seem as if these matchmaking and marriage narratives were grounded in habitual family storytelling events (as studied, e.g., by Brandes 1975, Dégh 1976, Langllier \& Peterson 2004, Oring 1984, Stone 1988, Yocom 1982, and Zeitlin \& Kotkin \& Baker 1982), in fact they were not because, as said, the narrating community went through extreme processes of persecution, immigration, and re-integration in a newly founded state and society. These processes turned them into a community whose bygone Diaspora experience was irrelevant to their offspring, though amongst themselves they did habitually reminisce their shared past. Therefore, for this specific JewishIsraeli group, family narratives and narrations are hardly part of their everyday experiences, but rather one of the topics they could discuss thanks to the opportunity afforded to them in recent decades by research projects of Israeli universities; hence the atmosphere and sense of salvaging, commemoration, and poignancy expressed in some of their narratives.

The six narratives chosen for this article (and two adjacent ones inserted to elucidate them) are, first and foremost, fragments of personal and family memories. However, they are also a reflection of the cultural milieu of these narrators and a historical testimony to the most horrific years for the Jewish people in the tumultuous 20 th century. In light of this realisation, my literarycultural analysis of the six narratives, focusing on the moments or moves of finding and/or losing one's mate rather than demonstrating comprehensive narrative examinations, is carried out on three levels: one, the poetic and structural elements of the narratives; two, the cultural elements (customs, norms, and taboos) of the narrating communities and, by extension, of Central and Eastern European Jewry in the first half of the 20th century; and three, the act of telling these narratives in the historical context of a bygone community whose few survivors strive to perpetuate their past lives through memories and stories. 


\section{NARRATIVES ABOUT MATCHMAKING AND MARRIAGE BETWEEN TRADITION AND MODERNITY}

Peretz Litman of Haifa (b. in Munkács/Mukačevo, in the western part of Carpatho-Rus', in 1926, and emigrated to Israel in 1950) describes in his interviewconversation with Zipora Nemesh his parents' marriage as a hybrid between an arranged match and a personal or familial acquaintance.

\section{Peretz Litman: The Arranged Marriage of Father and Mother}

My father and mother married through a matchmaker. So did my grandfathers and grandmothers. My aunt, Mother's sister, once saw [my future] Father on the train. He used to travel all week long due to his business. And she asked [around], "Who is this good-looking fellow?" They told her, "He is a single fellow from Munkács." So she said, "Maybe he'll suit my sister who is still unmarried." So they went to Munkács. You have to ask around, you know. So they asked, "What are these Litmans like?" They were told, "They are a very good family, [there is] only one problem, they are of Polish descent." But my mother was wise. She said, "I don't care about his origin, the important thing is that he is a good fellow." They brought him over to see [him/her]. They found favour in each other's eyes and married in 1924. He received the dowry in korunas [Czech currency], and put it in the bank. I only remember that in my childhood, when they used to argue, he would tell her, "You can go back to your village, take your money, it's still there in the bank. Take the money and go home." (The interviewer and the interviewee laugh together.) ${ }^{1}$

Eliezer Friedman of Haifa (b. in Munkács in 1914 and emigrated to I/P in 1939) also points to cultural gaps between his parents, yet in contrast to the Litmans' case, this gap is not economic or "ethno-regional", but concerns the religiosity difference and mental gap between the spouses in an era of accelerated modernisation.

\section{Eliezer Friedman: A Kiss? Only after the Wedding}

Mother used to tell about Father, how she fell in love with him. She used to say, "Er is geven a moderner yunger man" (Yid. "He was a modern/ secular young man'). In other words, in that Orthodox atmosphere, the story of my parents - [though] I repeatedly heard it as a boy - was not so simple, I didn't really understand it then. My mother told us that on their wedding day they went to register in the municipality. It was on the second floor, you [addressing interviewer Zipora Nemesh] remember our municipal council building, right? So after they registered and after they 
went down the staircase, this wide staircase, you remember? So Father approached her and wanted to give her a kiss. And she said, "No, not yet, only after the wedding." (The interviewer and the interviewee laugh.) That was exactly my mother's fate, caught between the conservative orthodoxy of her parents and Father's modernity and progress. ${ }^{2}$

Both of these two narratives dealing with the tension between tradition and modernity also have an equivalent version in documentary writings published in recent decades by the same narrators or by their family members. In his printed autobiography, Peretz Litman devotes much attention to descriptions of his town of Munkács, the various Jewish groups that lived there, and the Polish origin of his family (Litman 1996). Eliezer Friedman's younger sister, Rachel Bernheim-Friedman, emphasises in her Holocaust memoir the religiosity and mentality gap between their parents. The parents married just before World War I, and the gulf between them grew after the father's military service during the war, when he was exposed to Jewish nationalism (Zionism), secularism, and the impact of generally more modern Central and Eastern European people and tendencies (Bernheim-Friedman 2005).

In Peretz Litman's oral narrative about his parents' match, the mother's married sister "once saw [my future] Father on the train. He used to travel all week long due to his business". The enterprising sister takes the initiative to look into the background and identity of "this good-looking fellow", in contradistinction to traditional norms and genres that attribute the discerning eye to the groom or his emissaries and beauty to the bride. The sister/aunt's inquiries reveal that there is "one problem": the fellow is of Polish(-Jewish) descent, which for Austro-Hungarians, including Jews, means inferiority despite the fact that Carpatho-Rus' itself was viewed by central-state Hungarians as a far-flung, God-forsaken region. Given this "problem", the bride/wife/mother is characterised by her son as "wise", because she is willing to consider the issue and the "fellow" despite the "problem" of his seemingly inferior provenance, as long as he is a "good fellow". At this point, the potential couple is allowed to meet: "They brought him over to see." Interestingly, Peretz uses the transitive verb "see" [Heb. lirot] without specifying the object "her", which enables an egalitarian reading of the act as a mutual "seeing" and scrutiny of the two.

Their son Peretz, who of course was not present during the matchmaking and marriage of his parents, clearly remembers things his parents said a few years later about their earlier period together, especially regarding the dowry that his mother brought into the marriage. It turns out that his father succeeded in his "business" and, as a result, never needed his wife's dowry, which he had deposited "there in the bank". Years later, during arguments between Peretz's parents, the father tells the mother that she can withdraw her money from 


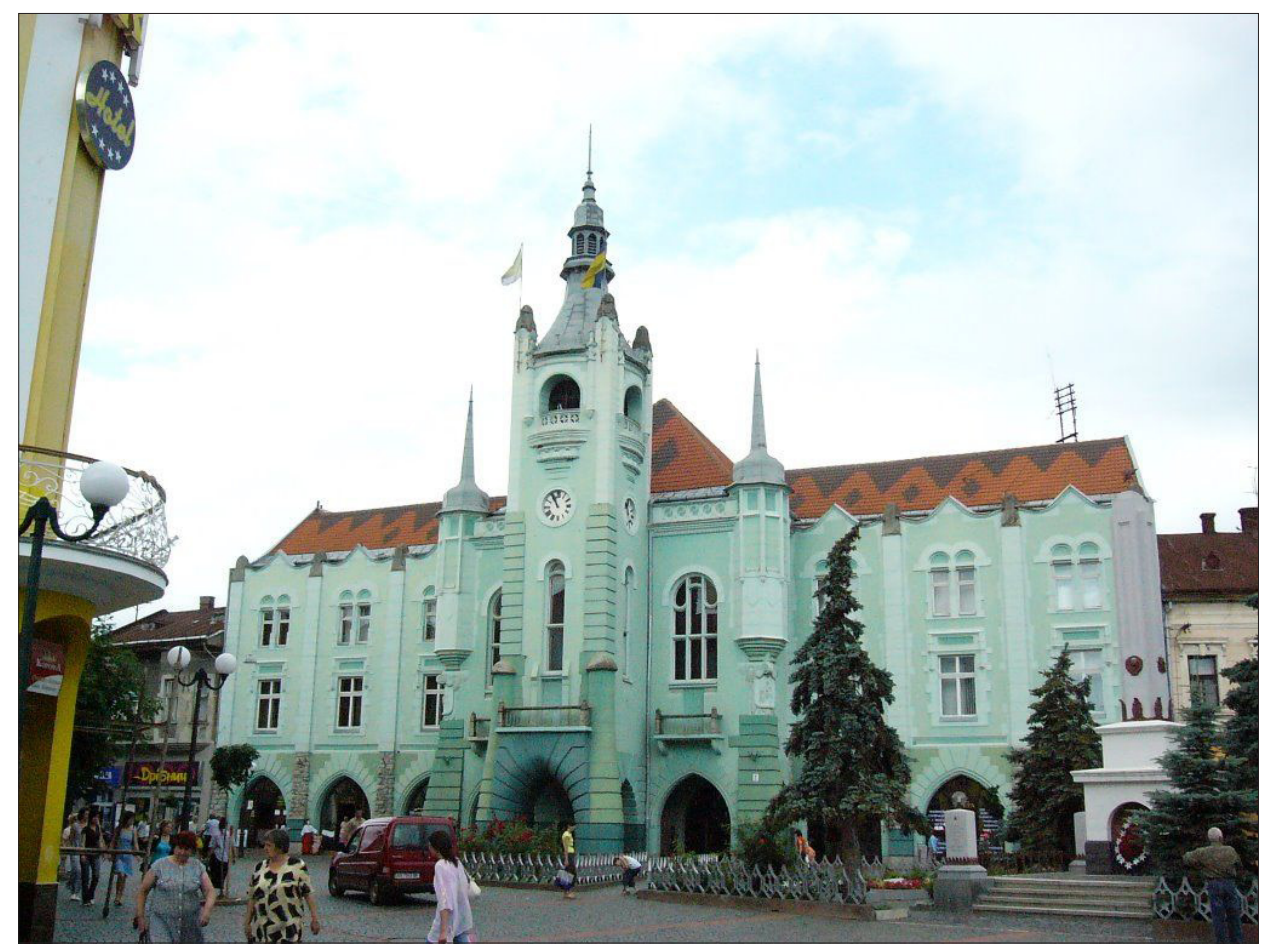

Figure 4. Munkács / Mukačevo City Hall today (http: / / www.panoramio.com / photo / 1256365).

the bank and "go back to [her] village", though this can likewise be the father's response to the mother's threat of taking her money and leaving. Thus, the later exchange of words becomes an echo of the "transaction" at the foundation of the marriage (Chiswick \& Lecker \& Kahana 2007). However, over the years the relative positions of the husband and wife have changed: while the groom's status was viewed as inferior in the matchmaking stage due to his foreign background and harder economic circumstances, now the relative superiority of the bride/wife no longer threatens the industrious groom/husband, who wisely built himself up economically and socially as a respectable Munkácser, which is another issue that Peretz emphasises throughout his book.

In Eliezer Friedman's narrative, the Jews of the town, as all other residents, had to register for civil marriage and declare their change in marital status to the municipality, in addition to the religious ceremony conducted close to the time of the civil registration. Apparently, the registration preceded the religious ceremony, which explains why the bride refused to be kissed once out of the 
municipality building. According to her belief and perspective, only the Jewish religious ceremony could transform her into a married woman and allow her to be touched by her husband. In effect, Eliezer's narrative demonstrates that although he announced in the beginning that it was a story about "how she [Mother] fell in love with him [Father]", it is really the story of their walk down the municipal building staircase after their civil marriage registration, and of his mother's refusal to see herself as married to his father so long as they were not married according to Jewish religious law.

Eliezer's sister Rachel, of Kibbutz Yakum (b. in Munkács in 1922 and emigrated to P/I in 1947), who published her memories as a Munkács native and Holocaust survivor in two different books (Bernheim-Friedman 1999; 2005), chose to focus on the story of the parents' earlier acquaintance, and that too only from the point of view of her future father:

My mother and father both came from very religious families. The "institution" of the shadkhan/shadkhen (Heb./Yid. 'matchmaker') was accepted at the time, and the only way that young women and men met one another before marriage was through the shadkhan. When Father reached the age of eighteen, the age deemed ready for the huppa (Heb. 'wedding canopy' and - by metonymic extension - 'ceremony'), the matchmakers started frequenting their home with good recommendations for a shiddukh (Heb. 'match'). Father rejected the pious, righteous potential brides offered to him, as well as the wealthy daughters of privileged families, and sent them [the matchmakers] directly to Mother's home. [That was because] he remembered her after he had seen her once, by chance, near a store. Her image was reflected in the store window and Father distanced himself a bit, then turned on his heels to look at her again. After a few days he returned to that same place, and he saw her again. He gazed at her and was certain that she would be the one he would lead to the huppa. That's why he sent the matchmakers to her house when they came to his parents' home. After a very short time, they were wed according to [Jewish] religion and law. It was love at first sight (Bernheim-Friedman 2005: 18).

In Rachel's over(t)ly romantic version, the initiative and the discerning eyes are attributed to the future groom, in contrast to the gaze of the intended bride's sister in Peretz Litman's narrative, while the intended or future bride never gets to function in the semantic role of an "agent", but only in that of a "recipient" (Bouchard 1995; Berk 1999). In this sense she is even less active than in Eliezer's narrative, in which she at least has a say about being kissed after the civil marriage and before the religious ceremony. Thus the two siblings, Rachel 
Figure 5. Rachel Bernheim-Friedman (http: / / www.mynet.co.il/ articles /0,7340,L-3640241,00.html).

and Eliezer, traverse in their narratives the continuum between tradition and modernity, romantic and realistic modes, and the hypothesised points of view of their father and mother, almost a hundred years after the event.

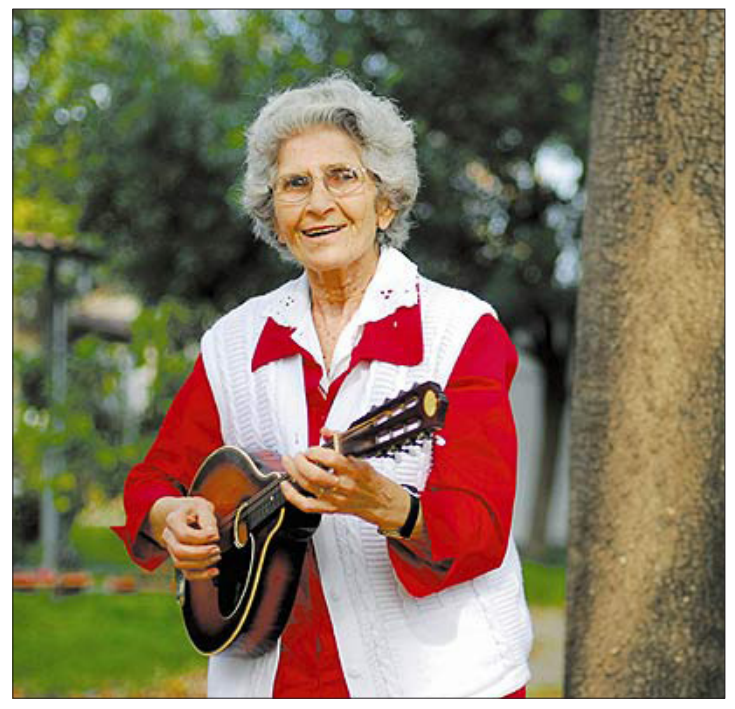

\section{NARRATIVES ABOUT MATCHMAKING AND MARRIAGE IN THE SHADOW OF THE HOLOCAUST}

In the narrative of Haya Adler of Kfar Sava (b. in Huszt/Chust, in the centralsouth of the region, in 1926, and emigrated to Israel in 1949), she describes the hardships endured by her older, idolised brother in his attempts to oppose the norm of arranged marriage for the sake of marrying a young woman that he met on his own. The tone of Haya's narrative is elegiac and lamenting, as it expresses her grief over the later loss of her beloved brother in the war, evidently in the Hungarian army labour battalions or "service" (Rosen 2012), before he was able to marry his sweetheart.

\section{Haya Adler: An Arranged Marriage vs. Courtship}

When they made a shiddukh, they were very careful that the families would suit one another; this was of great importance. My brother - the brother I spoke about earlier, the one whom the Rabbi wanted to take with him to Eretz ('Land of') Israel - he fell in love with a girl. He came home from yeshiva [institution for the study of Jewish holy scriptures] and went to drink something [in a coffeehouse]. It was customary for the young fellows to go to that place. And in that place, the [owner's or the manager's] daughter used to come in a lot, so he began to court her. At first it was all hush-hush, it took years, and it was not so simple. And then 
my parents found out and they got very angry. [They said:] "What kind of business is this, for a yeshiva bahur (Yid. yeshiva 'disciple/student'; Heb. bahur yeshiva), this is terribly inappropriate!” And the girl's family was not what my parents looked for, for him, because he was a very talented, special son. Out of the nine children, two were very talented, my oldest sister who was married, and he. Parents sense this kind of thing, when [a child is] very talented. Children are not all the same. And he [Father] said, "Especially for you, we will make a great shiddukh." They [the girl's family] were a beseder (Heb. 'okay') family, be'alei batim (Heb./Yid. 'house owners, economically secure'), but they were of Polish origin, so they used to say [condescendingly]: a poylishe (Yid. 'a girl from Poland'). It wasn't exactly what they wanted because they didn't know who their [the girl's family] ancestors were, didn't know their lineage, because they came from far away. In addition, my father opposed the match because it was based on courtship. That is not our style. And my brother suffered from this a lot, it took years. He went to the army, came back from the army, he was already twenty-plus years old and he courted her very seriously, he wanted very much to marry her. It was terrible at home, a real tisha $b^{\prime} a v$ (atmosphere of sorrow and mourning as on the Ninth of Av, the date on which, according to tradition, both Temples were destroyed). He fought for it. And I, as a child, I fought on his side. My brother suffered terribly for this. Then the parents relented, they saw how much he suffered and they agreed to the match, and really went through with the match. But unfortunately they never made it to a wedding, because of what came along [the Holocaust]. ${ }^{3}$

Another, adjacent narrative told by Haya, about an earlier stage in her brother's life, works to intensify the tragedy of his later death:

Haya Adler: In [our town of] Huszt there was a yeshiva gedolla (Heb. 'a higher-learning yeshiva') of Rabbi [Yosef Zvi] Dushinsky, and my brother studied there, [the brother] who disappeared in Russia later on. He was still a very young fellow then. Rabbi Dushinsky left for Eretz Israel in 1933 or 1934, I don't remember exactly. My brother was a very good student, keen and sharp-minded. He [the Rabbi] really loved him and invited Father over, [to ask him for permission] to take my brother with him to Eretz Israel. He [the Rabbi] says, "He is something, if he's near me, he will warm my heart." My Father went there and returned from the Rabbi, crying. He said, "What, should I send my child and never see him again in my life?" He did not agree. He did not allow him to go. But in the end, he [my brother] died in the war. It could be that if he had come here [to Israel], he would have remained alive. ${ }^{4}$ 


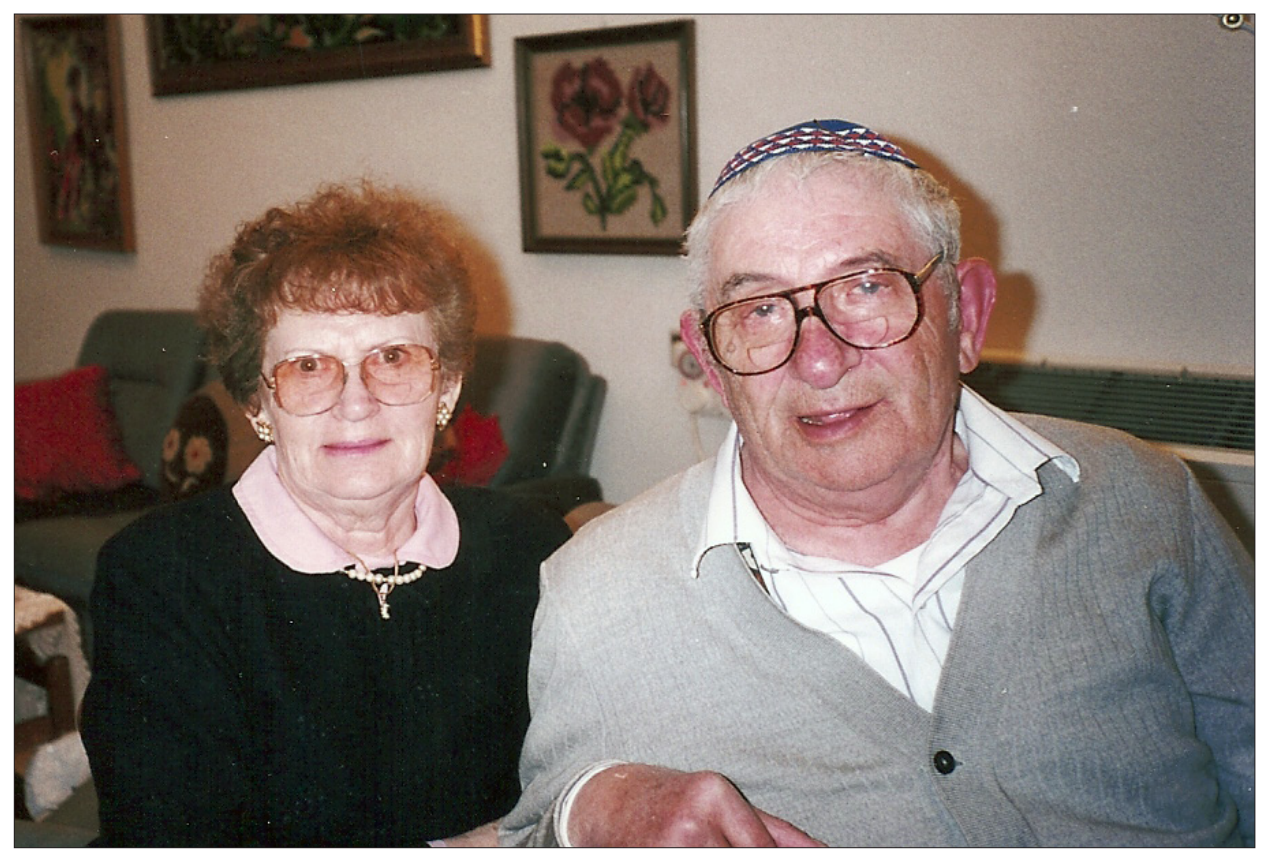

Figure 6. Haya and Shlomo Adler. Photograph by Sara Udi 1995.

According to this narrative, the brother had been a beloved disciple of Rabbi Yosef Zvi Dushinsky (1867-1948), Huszt's charismatic Rabbi, who left for Eretz Israel in 1933 (Rosen 1999: 38-43). Before his departure, the Rabbi asked the father of his outstanding and beloved student for permission to take his son along, but the father refused to part from his son and ultimately the son died in the Holocaust.

In the main narrative, the talented brother later met a girl from a "Polish background", a disparaging label as in Peretz Litman's narrative, and "he courted her very seriously, he wanted to marry her very much". Haya details the negotiation or struggle between her brother, with whom she identified in her childhood ("and I, as a child, I fought on his side"), and their parents. The parents resolutely opposed the match for three reasons: first, the girl was supposedly foreign and of inferior origin; second, the fact that the two met each other directly and not through a matchmaker; and, third, the parents' desire to execute the best possible economic and social "transaction" for this "very talented, special son" ("Especially for you, we will make a great shiddukh"). Haya emphasises the prolongation of the feud between the son and his parents: 
"It took years. He went to the army, came back from the army, he was already twenty-plus years old," and the gravity of the dispute: "It was terrible at home, a real tisha b'av." She also highlights the tenacity and suffering of the idolised brother: "My brother suffered terribly for this [...] He fought for it." Ultimately, after years, "the parents relented", meaning that they adjusted their values and expectations to the reality that their son set before them. But to Haya's great sorrow, as expressed in the repetition of the word "very" throughout both her narratives, the parental agreement arrived too late and the son/brother never enjoyed "life with the wife [he] loved" (Ecclesiastes 9:9).

The narrative of Oli (Olga) Klein, presently of Budapest, Hungary, and originally from Beregszász/Berehovo, in the western part of Carpatho-Rus', also revolves around a match that was unusual for its time and place and was never consummated because of the Holocaust.

\section{Oli (Olga) Klein: Engaged to a Non-Jewish Fellow}

It is quite hard for me to talk about it. At the age of seventeen I met a young fellow, not Jewish. After four years of great love, they took me to Auschwitz. He wanted to hide me, but I refused. [He] helped me in that he took my dowry [for safekeeping] - because it was fashionable at the time for young women, brides, to have dowries - and afterward, I received the dowry back. ${ }^{5}$

Oli never emigrated to Israel, and I made her acquaintance while she was visiting Israel and stayed with friends whom I interviewed as a group of formerly Carpatho-Rusyn Jews from Beregszász. She took part in the interview event, but I did not have the opportunity to learn more about her or record her full life history, as I did with others in that project (Rosen 1999: 79-86; 2004: 133-138); that is why Oli's short narrative remains unclear and enigmatic. Therefore, it is not clear whether Oli ever married her non-Jewish boyfriend, or why she did not accept his offer to hide and protect her from deportation to Auschwitz. Between the lines we can glean that after her return from the camps, the distance between Oli and her Christian boyfriend grew and they could not continue the "great love" they had had before the Holocaust (for a novelised depiction of the gap between a camp survivor and his wife see: Duras 1994 [1985]). It is also reasonable that she enlarges on the custom of the dowry to compensate for her inability to talk more about her first fiancé and their relations. 


\section{NARRATIVES ABOUT MATCHMAKING AND MARRIAGE ON THE WAY TO I/P}

In contrast to the narratives of Haya Adler and Oli Klein, the narrative of Shoshana Meron of Ra'anana (b. in Brod/Brid, in the centre of the region, in 1928, and emigrated to Israel in 1948) ends on an optimistic note: the match at the heart of the narrative turns out to be successful and the couple is spared the fate of most of the Jews in their region during the Holocaust.

\section{Shoshana Meron: A Bridegroom from Eretz Israel}

There was a family without the father [who had died]. There was [only] the mother. There were some six daughters. You know, a widow, to support six daughters, to marry them off, it was impossible, really. An uncle of theirs lived here [in Eretz Israel]. So he sent bridegrooms for the daughters, fellows from Israel. The last one that came, it was during the period when the Hungarians were in charge [ruled over CarpathoRus' in 1939-1945]. And this Yemenite [-Jewish] fellow showed up. How did I, we, even know that he was Yemenite? We didn't know anything about Yemenites. He arrived. He was small, dark, like a gypsy. But he didn't speak [Yiddish], only Hebrew. So the family came to ask [my] Father to come and talk to him, translate him. He [Father] knew Hebrew but spoke it with an ashkenazi [European Jewish] accent. Father was the only liaison to connect this man, this fellow, to that family. He was a Yemenite, she was scrawny, transparent as cellophane, nothing but skin and bones, with blue eyes. He wasn't so excited about her. He wanted the shikses [Yid. colloq., derog. 'non-Jewish women'], the strong, healthy gentile women. And he did start to fool around after some time, to make contacts with everyone. Meanwhile he learned Yiddish, he knew a little Russian. And he did not want to get married. Ah, no, she did not want to marry him. That didn't bother him, but he couldn't return [to I/P] because they closed the borders. So they went anyway... Wait, no, that was when they were still under Czech rule [in the interwar period]. He travelled to Prague and tried to get a certificate from the British embassy [to enter I/P]. They didn't give it to him. So he came back and said, now that I [know that I] am not returning [to I/P], I do want to marry her. And they got married. And they actually went back to Prague and went on aliya [Heb. 'emigration'] to Eretz Israel. She survived and [they] live to this very day. I even visited them in Zichron Yaakov [south of Haifa]. They are alive and well to this very day. ${ }^{6}$ 
In Shoshana's narrative the contrast between different identity groups is even more prominent than in the others, as it features the following contrasts: Eretz Israeli Jews vs. Central and Eastern European Jews; Yemenite Jews vs. Austro-Hungarian Jews; and "scrawny", "transparent" Jewish girls vs. "strong", "healthy" Christian girls. At first the intended bride and groom view one another with disfavour ("And he did not want to get married. Ah, no, she did not want to marry him. That didn't bother him"). Afterwards, the fellow wants to go back to Eretz Israel but he is blocked by the British Mandate authorities that rule the country. Now he does want to marry his "skin and bones" match, and she wants him, and the two ultimately succeed in making their way to Eretz Israel.

Among the hundreds of narratives I recorded for my two Carpatho-Rusyn research projects, there is a long, complicated narrative by a woman who managed to leave the region by means of a fictitious marriage, but later faced difficulties in releasing herself from the marriage bonds. ${ }^{7}$ Both that narrative and this one demonstrate that married couples, real or fictitious, had fewer difficulties making their way to I/P than did single individuals, because Jewish organisations mediating between the emigrants and British Mandate authorities preferred to grant the coveted immigration license or "certificate" to couples over singles. Thus it is likely that the two agreed to marry, following their initial reluctance, because around 1939 they realised that marriage was their only way to leave for Eretz Israel. Yet their union, which was originally based on the desire to flee Europe rather than for each other, withstood the test of time, and the two remained a couple long after, "to this very day", in Shoshana's fairytale-like wording.

Like Shoshana Meron's narrative, the narrative of Zipora Nemesh (b. in Munkács in 1919 and emigrated to Israel in 1956) also carries an anticlimactic undertone as it features an unromantic relationship based on practical circumstances rather than on mutual attraction.

\section{Zipora Nemesh: How I Met My Husband}

In 1946 I married my husband, Moshe Géza Nemesh, who had a doctorate in chemistry. We lived together for forty-eight years. Eight months ago he passed away. After the war I worked with children. In 1946 they decided that I would make aliya with a group of orphaned children. We travelled to Budapest with this group and there my future husband - I didn't know him then - entered the same railway carriage [as the children and I]. He always wanted to help me and take care of the children, until the children asked, "Where is your fellow?" and I reciprocated, "What fellow?" And they said, "Géza”. I didn't know that he was my "fellow". Afterwards, he 
helped me so much with taking care of the children until we really became a couple and we returned to Hungary because he wanted to introduce me to my parents, sorry, his parents. And we wed in $1946 .^{8}$

In Zipora's case the anticlimatic tone may derive also from her being a newly bereaved widow at the time of the interview, in which she seemed unable or unwilling to delve into emotional issues and, instead, summarised her fortyeight years of marriage in three sentences. She then proceeds and turns the clock back fifty years, to the period when she met her future husband during her work as counsellor of orphaned Holocaust survivor Jewish children on their way to Eretz Israel (on the reconstruction of families and educational frames by Jewish displaced persons (DPs) following World War II see: Baumel 1997). Here, too, the narrative is not romantic: while she is aware of Dr. Moshe-Géza's presence and assistance in taking care of the children, Zipora does not view him as a potential beau or candidate for marriage. The ones to make the connection or "match" between Zipora and her future husband are the children in her care: "The children asked, 'Where is your fellow?', and I reciprocated, 'What fellow?' And they said, 'Géza'. I didn't know that he was my "fellow"."

In the early post-Holocaust period, following the total destruction of Jewish families and their traditional frames and authorities, the orphaned children act as matchmakers for this couple that actually holds a parental role in their lives. Soon afterwards, after "[they] really became a couple", the two travel to the husband's parents in Hungary to officially introduce the bride. This act symbolically returns the functions of matchmaking and marrying off children to the hands of the older generation. But Zipora's slip of the tongue, "to introduce me to my parents, sorry, his parents", serves as inadvertent testimony to the rupture remaining in her consciousness despite the ostensibly happy ending, since Zipora's parents and most of her family and community were lost in the Holocaust. Furthermore, the children that she nurtured and educated throughout her life, from Munkács in her youth to Haifa in her middle and old age, remained the only children that she ever had, as she and Moshe-Géza never had any children of their own. 


\section{CONCLUSION: NARRATIVE AS COMMEMORATION OF A LOST COMMUNITY}

In summary, in this article I have examined a group of narratives dealing with matchmaking and marriage among the Jews of Carpatho-Rus' between the two world wars, as narrated and documented in Israel around the end of the 20th century. The narratives about the marriages of the parents of the intervieweenarrators testify to the tension between tradition and modernity, or devoutness and secularism, as well as to the sensitivity and wariness of Carpatho-Rusyn Jews vis-à-vis other, "foreign" Jews, mainly those with more eastern Polish roots. The narratives about matchmaking and informal acquaintances in the shadow of the Holocaust carry an overtly tragic note, as they express sorrow over the loss of the life and love that existed before the Holocaust. Finally, the narratives about relationships that were formed slightly before or after the Holocaust and led the couples to Israel conclude on a positive note. However, they also contain an anti-climactic tinge as these matches and courtships emerge as "defaults", due to the atmosphere of danger and demise that hovered above their protagonists during that period, similarly to the majority of European Jewry.

When reading these narratives of matchmaking and marriage as a whole, we learn about the Carpatho-Rusyn Jewish communities of the interwar period, which were largely lost in the Holocaust. We gain knowledge of their self-images as well as their images (or imaginings) of Others, such as Jews from near or faraway places, of different classes, complexion, religious style, as well as of non-Jews. Accordingly, we realise their readiness or reluctance to tie their lives with these Others and thus reconsider or even change their age-old persuasions, with the threat of destruction adding an extra twist or "turn of the screw" to their dilemmas. The unexpected unfolding of some of the narratives offers insights concerning the wishes, needs, and necessities of these people as anchored in their time, place, mentality, cultural setting, and specific life circumstances. Evidently, harsh life, war, and destruction may have changed their views and choices but not their preferences and tastes as preserved in their narratives even over fifty years after the event. All this points to the importance of memory, memorialisation, story, and reflection for these narrators who, in their golden years in Israel at the end of the 20th century, attempt to recreate their past vanished lives, families, communities, and entire worlds as vividly and faithfully as they can. 


\section{NOTES}

1 Peretz Litman, Haifa, Israel; interviewed in 1995 by Zipora Nemesh, transcribed by Ilana Rosen; the Dov Noy Israeli Folktale Archives (IFA) at Haifa University, IFA serial no. 23831. All Hebrew narratives for this article were translated by Sandy Bloom.

${ }^{2}$ Eliezer Friedman, Haifa, Israel; interviewed in 1995 by Zipora Nemesh, transcribed by Ilana Rosen, IFA 23323.

${ }^{3}$ Haya Adler, Kfar Sava, Israel; interviewed in 1995 by Sara Udi, transcribed by Ilana Rosen, IFA 23203.

4 Haya Adler, Kfar Sava, Israel; interviewed in 1995 by Sara Udi, transcribed by Ilana Rosen, IFA 23201.

5 Oli Klein, Budapest, Hungary; interviewed in 1995 (in Israel), translated from Hungarian into Hebrew and transcribed by Ilana Rosen; Archives of the Research Project of the Jews of Carpatho-Rus' and Munkács/Mukachevo, the Goldstein-Goren Diaspora Research Center at Tel Aviv University, file Ehrlich, item no. 26.

6 Shoshana Meron, Ra'anana, Israel; interviewed in 1995, transcribed by Ilana Rosen, IFA 23846.

7 Tova Noyman, Netanya, Israel; interviewed in 1995, transcribed by Ilana Rosen, IFA 23645.

8 Zipora Nemesh, Haifa, Israel; interviewed in 1995, transcribed by Ilana Rosen, IFA 23859 .

\section{ARCHIVAL SOURCES}

Archives of the research project of the Jewry of Carpatho-Rus' and Munkács/Mukachevo, the Goldstein-Goren Diaspora Research Center at Tel Aviv University

The Dov Noy Israeli Folktale Archives (IFA) at Haifa University

Archives of the Institute for Contemporary Jewry of the Hebrew University in Jerusalem

\section{REFERENCES}

Baskin, Judith R. 2010. Jewish Private Life: Gender, Marriage, and the Lives of Women. In: Judith R. Baskin \& Kenneth Seeskin (eds.) The Cambridge Guide to Jewish History, Religion, and Culture. New York: Cambridge University Press, pp. 357380 .

Baumel, Judith Tydor 1997. DPs, Mothers and Pioneers: Women in the She'erit Hapletah. Jewish History, Vol. 11, No. 2, pp. 99-110. http://dx.doi.org/10.1007/BF02335680. 
Berger, Michael S. 2005. Marriage, Sex, and Family in the Jewish Tradition: A Historical Overview. In: Michael J. Broyde \& Michael Ausubel (eds.) Marriage, Sex, and Family in Judaism. Lanham, MD: Rowman \& Littlefield Publishers, pp. 1-14.

Berk, Lynn M. 1999. English Syntax: From Word to Discourse. New York: Oxford University Press.

Bernheim-Friedman, Rachel 1999. ha-Or bi-ketseh ha-minharah kavah. [The Light at the End of the Tunnel Went Out.] Tel Aviv: Miśrad ha-bitahon.

Bernheim-Friedman, Rachel 2005. Earrings in the Cellar: Growing Up in Ruined Worlds. Transl. by Anthony Berris and Miriam Talisman. Jerusalem \& Lynbrook, NY: Gefen Publishing House.

Biale, David 1983. Love, Marriage, and the Modernization of the Jews. In: Marc Lee Raphael (ed.) Approaches to Modern Judaism 1. Chico, CA: Scholars Press, pp. 1-17.

Bouchard, Denis 1995. The Semantics of Syntax: A Minimalist Approach to Grammar. Chicago, IL: University of Chicago Press.

Brandes, Stanley H. 1975. Family Misfortune Stories in American Folklore. Journal of the Folklore Institute, Vol. 12, No. 1, pp. 5-17. http://dx.doi.org/10.2307/3813966.

Broyde, Michael J. \& Michael Ausubel (eds.) 2005. Marriage, Sex, and Family in Judaism. Lanham, MD: Rowman and Littlefield Publishers.

Bulka, Reuven P. 1989. The Dynamics of Jewish Marriage. Journal of Psychology and Judaism, Vol. 13, No. 2, pp. 73-86.

Chiswick, Carmel U. \& Lecker, Tikva \& Kahana, Nava (eds.) 2007. Jewish Society and Culture: An Economic Perspective. Ramat Gan: Bar Ilan University Press.

Dégh, Linda 1976. Symbiosis of Joke and Legend: A Case of Conversational Folklore. In: Linda Dégh \& Henry Glassie \& Felix J. Oinas (eds.) Folklore Today. Bloomington, IN: Indiana University Press, pp. 101-122.

Duras, Marguerite 1994 [1985]. The War: A Memoir. Transl. by Barbara Bray. New York: Pantheon Books.

Greenbaum Ucko, Lenora 1990. Who Are the Wives? Who Are the Husbands? A Study of Marriage Roles in Jewish Classical Folktales. Jewish Folklore and Ethnology Review, Vol. 12, Nos. 1-2, pp. 5-10.

Grossbard, Shoshana 2007. Competitive Marriage Markets and Jewish Law. In: Carmel U. Chiswick \& Tikva Lecker \& Nava Kahana (eds.) Jewish Society and Culture: An Economic Perspective. Ramat Gan: Bar Ilan University Press, pp. 55-84.

Hann, Chris 2006. Peripheral Populations and the Dilemmas of Multiculturalism: The Lemkos and the Lazi Revisited. In: Bogdan Horbal \& Patricia Krafcik \& Elaine Rusinko (eds.) Carpatho-Rusyns and their Neighbors: Essays in Honor of Paul Robert Magocsi. Fairfax, VA: Eastern Christian Publications, pp. 185-202.

Jackson, Bernard S. 2011. The 'Institutions' of Marriage and Divorce in the Hebrew Bible. Journal of Semitic Studies, Vol. 56, No. 2, pp. 221-251. http://dx.doi.org/10.1093/ jss/fgr002.

Jelinek,Yeshayahu A. 2007. The Carpathian Diaspora: The Jews of Subcarpathian Rus' and Mukachevo, 1848-1948. Boulder, CO \& New York: East European Monographs \& Columbia University Press.

Kaplan, Marion A. \& Moore, Deborah Dash (eds.) 2011. Gender and Jewish History. Bloomington, IN: Indiana University Press. 
Langllier, Kristin M. \& Peterson, Eric E. 2004. Storytelling in Daily Life: Performing Narrative. Philadelphia, PA: Temple University Press.

Litman, Peretz 1996. Hana'ar mimunkatsh: sipuro shel nitsol. [The Boy from Munkács: The Story of a Survivor.] Haifa: author's edition.

Lowenstein, Steven M. 1994. Ashkenazic Jewry and the European Marriage Pattern: A Preliminary Survey of Jewish Marriage Age. Jewish History: The Robert Cohen Memorial Volume. Vol. 8, Nos. 1-2, pp. 155-175. http://dx.doi.org/10.1007/ BF01915912.

Magocsi, Paul Robert 1974. An Historiographical Guide to Subcarpathian Rus'. Cambridge, Mass.: Harvard Ukrainian Research Institute \& Harvard University.

Novak, David 2005. Jewish Marriage: Nature, Covenant, and Contract. In: Michael J. Broyde \& Michael Ausubel (eds.) Marriage, Sex, and Family in Judaism. Lanham, MD: Rowman \& Littlefield Publishers, pp. 61-87.

Ochs, Vanessa L. 2011. Same-Sex Marriage Ceremonies in a Time of Coalescence. Jewish Cultural Studies, Vol. 3. Revisioning Ritual: Jewish Traditions in Transition, pp. 190-210.

Oring, Elliott 1984. Dyadic Traditions. Journal of Folklore Research, Vol. 21, No. 1, pp. 19-28. Available at http://www.jstor.org/discover/10.2307/3814341?uid=373 $7920 \&$ uid $=2129 \&$ uid $=2 \&$ uid $=70 \& u i d=4 \& \operatorname{sid}=21105132800073$, last accessed on November 5, 2014.

Orla-Bukowska, Annamaria 2004. Maintaining Borders, Crossing Borders: Social Relationships and the Shtetl. Polin: Studies in Polish Jewry, Vol. 17, pp. 171-195.

Rosen, Ilana 1999. Ma'ase she-haya.... Hasiporet ha'amamit shel yehudey karpatorus. [Once There Was...: The Oral Tradition of the Jews of Carpatho-Rus'.] Tel Aviv: The Diaspora Research Institute.

Rosen, Ilana 2004. Be-Auschwitz takanu be-shofar - yotsey karpatorus mesaprim al ha-shoah. [In Auschwitz We Blew the Shofar: Carpatho-Rusyn Jews Remember the Holocaust.] Jerusalem: Yad Vashem \& the Avraham Harman Institute for Contemporary Jewry at the Hebrew University.

Rosen, Ilana 2008. Hasidism versus Zionism as Remembered by Carpatho-Russian Jews between the Two World Wars. Jewish Cultural Studies, Vol. 1. Jewishness: Expression, Identity, and Representation, pp. 213-238.

Rosen, Ilana 2009. Personal Historical Narrative Shaping the Past and the Present. European Journal of Jewish Studies, Vol. 3, No. 1, pp. 103-133. http://dx.doi.or g/10.1163/102599909X12471170467402.

Rosen, Ilana 2012. Soldiers or Slaves? Narratives of Survivors of the Hungarian Army's 'Labor Service' in World War II and the Holocaust. Dapim: Studies on the Holocaust, Vol. 26, No. 1, pp. 95-123. http://dx.doi.org/10.1080/23256249.2 012.10744417.

Rothkirchen, Livia 1977. Deep-Rooted Yet Alien: Some Aspects of the History of the Jews in Subcarpathian Ruthenia. Yad Vashem Studies, Vol. 12, pp. 147-191.

Rozenblit, Marsha L. 2011. Jewish Courtship and Marriage in 1920s Vienna. In: Marion A. Kaplan and Deborah Dash Moore (eds.) Gender and Jewish History. Bloomington, IN: Indiana University Press, pp. 88-103.

Rusinko, Elaine 2003. Straddling Borders: Literature and Identity in Subcarpathian Rus'. Toronto \& Buffalo \& London: University of Toronto Press. 
Segal, Raz 2013. Days of Ruin: The Jews of Munkács during the Holocaust. Transl. by Naftali Greenwood. Jerusalem: Yad Vashem.

Shenhar, Aliza 1983. The Jewish Oicotype of the Predestined Marriage Folktale: AaTh 930E (IFA). Fabula, Vol. 24, Nos. 1-2, pp. 43-55. DOI: 10.1515/fabl.1983.24.12.43 .

Stone, Elizabeth 1988. Black Sheep and Kissing Cousins: How Our Family Stories Shape Us. New York: Times Books.

Yocom, Margaret R. 1982. Family Folklore and Oral History Interviews: Strategies for Introducing a Project to One's Own Relatives. Western Folklore, Vol. 41, No. 4, pp. 251-274. http://dx.doi.org/10.2307/1499570.

Zeitlin, Steven J. \& Kotkin, Amy J. \& Baker, Holly Cutting (eds.) 1982. A Celebration of American Family Folklore: Tales and Traditions from the Smithsonian Collection. New York: Pantheon Books. 